\title{
Aplikasi Ragam Media Tanam pada Pertumbuhan dan Hasil Tanaman Temulawak (Curcuma xanthorrhiza Roxb)
}

\author{
Farida $^{1^{\star}}$, Nani Rohaeni ${ }^{2}$, dan Dian Triadiawarman ${ }^{3}$ \\ 1,2,3 Program Studi Agroteknologi, Sekolah Tinggi Pertanian Kutai Timur \\ Jl. Soekarno-Hatta No. 1 Sangatta, Kutai Timur \\ ${ }^{1}$ Email: farida@stiperkutim.ac.id \\ 2 Email: nanirohaeni@stiperkutim.ac.id \\ *Penulis korespondensi: farida@stiperkutim.ac.id
}

Revisi: 28-10-2021

Diterima: 3-12-2021

\begin{abstract}
Land productivity is one of the determining factors in production capacity enhancing of a commodity. Productive land is the land that afford to provide the nutrient needs for plants. Land degradation and marginal land that had been occurred was triggered a cultivation pattern in home garden, especially for a medicinal plants species. Research aimed was to determine the influence and the best of planting media for the growth and yield of Curcuma xanthorrhiza Roxb. The research was conducted for 7 (seven) months started on November 2020 up to May 2021. The non-factorial designs with 6 (six) replication based on the Randomized Block Design was used in this research. The treatment of planting media i.e. $M 1=$ Soil, $M 2=$ soil + husk 1:2 (2.5 kg: $5 \mathrm{~kg}), M 3=$ soil + roasted husks $1: 2(2.5 \mathrm{~kg}: 5 \mathrm{~kg}), M 4=$ soil + sawdust 1:2 (2.5 kg: $5 \mathrm{~kg}), M 5$ = soil + roasted sawdust 1:2 $(2.5 \mathrm{~kg}: 5 \mathrm{~kg})$. The research result showed that the planting media treatment had a significant effect on plant height and number of leaves parameters aged 4 months after planting (MAP), but nonsignificant effect on other parameters. The best treatment was roasted husks planting media treatment (M3) due to it produce the heaviest weight of fresh rhizome per clump i.e. 108.50 gram.
\end{abstract}

Keyword: Cultivation, Curcuma xanthorrhiza Roxb, Husk, Planting Media, Sawdust

\section{ABSTRAK}

Produktivitas lahan menjadi salah satu faktor penentu dalam peningkatan kapasitas produksi suatu komoditi. Lahan yang produktif adalah lahan yang mampu menyediakan kebutuhan unsur hara bagi tanaman. Degradasi lahan yang telah terjadi maupun lahan marjinal memicu pola budidaya di pekarangan rumah khususnya untuk jenis tanaman obat-obatan. Penelitian ini bertujuan untuk mengetahui pengaruh media tanam serta untuk mengetahui media tanam yang terbaik bagi pertumbuhan dan hasil tanaman temulawak (Curcuma xanthorrhiza Roxb). Penelitian ini dilaksanakan selama 7 (tujuh) bulan mulai dari bulan November 2020 sampai bulan Mei 2021 Rancangan yang digunakan dalam penelitian ini adalah Rancangan Acak Kelompok (RAK) Non factorial dengan 6 (enam) kali ulangan. Perlakuan media tanamnya yaitu $\mathrm{M} 1=$ Tanah, $\mathrm{M} 2=$ tanah + sekam perbandingan $1: 2(2,5 \mathrm{~kg}: 5 \mathrm{~kg}), \mathrm{M} 3=$ tanah + sekam bakar perbandingan 1:2 $(2,5$ $\mathrm{kg}: 5 \mathrm{~kg}), \mathrm{M} 4=$ tanah + serbuk gergaji perbandingan $1: 2(2,5 \mathrm{~kg}: 5 \mathrm{~kg}), \mathrm{M} 5=$ tanah + serbuk gergaji bakar perbandingan 1:2 $(2,5 \mathrm{~kg}: 5 \mathrm{~kg})$. Hasil penelitian adalah Perlakuan media tanam sangat berpengaruh nyata pada parameter tinggi tanaman dan jumlah daun umur 4 BST, tetapi tidak berpengaruh nyata terhadap parameter lainnya. Perlakuan media tanam sekam bakar (M3) merupakan perlakuan yang terbaik, karena menghasilkan berat rimpang segar per rumpun yang terberat yaitu 108,50 gram.

Kata kunci: Budidaya, Media Tanam, Sekam, Serbuk Gergaji, Tanaman Temulawak 


\section{Pendahuluan}

Produktivitas lahan menjadi salah satu faktor penentu dalam peningkatan kapasitas produksi suatu komoditi. Lahan yang produktif adalah lahan yang mampu menyediakan kebutuhan unsur hara bagi tanaman. Degradasi lahan yang telah terjadi maupun lahan marjinal memicu pola budidaya di pekarangan rumah khususnya untuk jenis tanaman obatobatan.

Salah satu tanaman obat tradisional yang digunakan secara luas dikalangan sosial masyarakat Indonesia secara historis adalah tanaman temulawak, sehingga sebagian besar kalangan menggunakan dan memanfaatkan temulawak sebagai obat khas Indonesia. Salah satu tanaman obat adalah temulawak (Curcuma xanthorrhiza Roxb) keluarga Zingeberaceae, yang dapat digunakan secara tunggal maupun campuran (Afifah \& Lentera, 2005).

Tanaman temulawak memerlukan media tanam yang sesuai untuk pertumbuhan dan perkembangannya, terutama untuk pertumbuhan dan perkembangan rimpang. Tanaman ini dapat tumbuh optimal pada tanah yang kaya bahan organik dan gembur (Nihayati, 2016). Dalam menghasilkan rimpang yang baik untuk temulawak, maka harus memperhatikan kondisi media tanamnya. Media tanam yang diinginkan oleh rimpang temulawak adalah media yang tidak hanya memiliki ketersediaan air, namun harus ada ketersediaan unsur hara sebagai nutrisi tanaman dengan jumlah yang cukup bagi tanaman, sehingga tanah yang diharapkan bagi pertumbuhan rimpangnya adalah tanah dengan sifat fisik yang baik yaitu aerasi dan agregat tanah yang baik, gembur serta cukup ruang untuk perakaran.

Media tanam yang diaplikasikan harus sesuai dengan kriteria yaitu ada ketersediaan unsur hara, oksigen dan air bagi pertumbuhan tanaman. Media tanam yang baik akan memberikan pertumbuhan dan hasil yang optimal bagi tanaman budidaya. Menurut Putri (2006), media tanam arang sekam merupakan media tanam yang praktis karena sudah tersterilkan dari cendawan yang merugikan. Hal ini disebabkan karena mikroba pathogen akan mati selama proses pembakaran. Selain itu, arang sekam merupakan media tanam yang porous atau gembur dan juga memiliki kandungan karbon $(C)$ yang cukup tinggi. Berdasarkan hasil penelitian Kusuma et al., (2013), diketahui bahwa arang sekam memiliki kemampuan sebagai absorban serta dapat menekan jumlah mikroba pathogen serta logam-logam yang berbahaya dalam pembuatan kompos yang bebas dari penyakit.

Serbuk gergaji dapat dijadikan media tanam alernatif yang bisa digunakan selain arang sekam. Serbuk gergaji adalah limbah buangan dari industri pengolahan kayu non kertas. Sifat dari serbuk gergaji adalah porositasnya cukup tinggi sehingga mudah diatur kepadatannya dengan dengan pengaturan rasio pemberian air. Kekurangan dari media tanam serbuk gergaji yakni mudah terjangkit jamur sehingga membuat akar tanaman yang 
dibudidayakan menjadi busuk akibat dari aktivitas jamur tersebut adalah dapat menghasilkan suhu yang cukup tinggi. Langgeng et al., (2019), menyatakan serbuk gergaji pada umumnya digunakan untuk budidaya jamur tiram. Namun beberapa serbuk gergaji masih terdapat getah yang dapat menghambat pertumbuhan tanaman. Pemanfaatan serbuk gergaji kayu sengon untuk persemaian cabai dilakukan dengan perendaman dalam air selama 5 hari menghasilkan perlakuan terbaik dengan panjang akar 6,08 cm.

Berdasarkan uraian diatas, perlu kiranya melakukan penelitian tentang uji pertumbuhan dan hasil tanaman temulawak (Curcuma xanthorrhiza Roxb) dengan berbagai media tanam. Penelitian ini bertujuan untuk mengetahui pengaruh dan jenis media tanam yang terbaik terhadap pertumbuhan dan hasil tanaman temulawak.

\section{Metode Penelitian \\ Waktu dan Tempat}

Pelaksanaan penelitian dilakukan pada bulan Juli 2020 sampai Januari 2021 yang bertempat di Jalan Poros Kabo Gang Kampung Jawa Swarga Bara Kabupaten Kutai Timur.

\section{Alat dan Bahan}

Penelitian ini menggunakan alat-alat sebagai berikut cangkul, parang, kamera, ember, pisau, meteran, timbangan dan alat tulis, sedangkan bahan yang digunakan yaitu polybag dengan ukuran $15 \mathrm{~cm} \times 15 \mathrm{~cm}$, bibit temulawak, tanah lapisan atas (topsoil), sekam, sekam bakar, serbuk gergaji, dan serbuk gergaji bakar.

\section{Rancangan Penelitian}

Penelitian ini menggunakan Rancangan Acak Kelompok (RAK) Non Faktorial dengan 6 kali ulangan. Faktornya yaitu media tanam: M1 = Tanah, M2 = tanah + sekam perbandingan 1:2 (2,5:5 kg), M2 = tanah + sekam perbandingan 1:2 (2,5:5 kg), M3 = tanah + sekam bakar perbandingan 1:2 (2,5:5 kg), M4 = tanah + serbuk gergaji perbandingan $1: 2(2,5: 5 \mathrm{~kg}), \mathrm{M} 5$ = tanah + serbuk gergaji bakar perbandingan 1:2 (2,5:5 $\mathrm{kg})$.

\section{Prosedur Penelitian}

Prosedur penelitian meliputi:

1. Persiapan bahan tanam

Bahan tanam yang digunakan adalah temulawak yang telah berumur tua umur 10 bulan. Rimpang induk dan rimpang cabang dipisahkan. Rimpang induk adalah rimpang yang akan digunakan sebagai bahan tanam penelitian. Rimpang induk dibelah menjadi beberapa bagian dengan syarat masing-masing rimpang yang telah dibelah memiliki berat yang sama rata yakni 30 gram, lalu dilakukan penyemaian. Rimpang yang telah mengeluarkan tunas-tunas baru, akan digunakan sebagai bahan tanam dalam penelitian ini. 
2.. Persiapan lahan

Persiapan lahan dilakukan dengan menggunakan parang dan secara manual dengan membersihkan lahan yang akan digunakan dari gulma maupun tumbuhan lainnya. Dipersiapkan petakan sesuai pada layout yang telah dibuat. Diukur jarak tanam yang akan digunakan. Bahan media tanam yang akan digunakan sesuai dengan perlakuan (sekam, sekam bakar, serbuk gergaji, serbuk gergaji bakar) dipersiapkan. Media tanam sesuai dengan komposisi masing-masing perlakuan dimasukkan.

\section{Penanaman}

Dipersiapkan bibit temulawak yang sebelumnya telah melalui proses penyemaian dengan tinggi tanaman semaian pada saat itu adalah $2 \mathrm{~cm}$. Bibit temulawak diletakkan ke dalam lubang tanam pada polybag dengan kedalaman $10 \mathrm{~cm}$. Lubang tanam tersebut ditimbun dengan media tanam yang sama.

\section{Perawatan}

Penyiraman dilakukan secara rutin setiap hari pada pagi dan sore hari atau tergantung dari kondisi di lapangan. Penyiangan gulma dilakukan secara manual dengan cara mencabut gulma secara hati-hati agar tidak merusak perakaran rimpang temulawak.

\section{Panen}

Tanaman temulawak dipanen pada saat telah berumur 7 bulan setelah tanam. Pemanenan rimpang temulawak dilakukan dengan cara membongkar rimpang dari dalam media tanam pada polybag. Selanjutnya rimpang dibersihkan, kemudian ditimbang.

\section{Parameter Pengamatan}

Parameter pengamatan yaitu:

1. Tinggi tanaman $(\mathrm{cm})$

Tinggi tanaman temulawak diukur dengan menggunakan meteran pada umur 2, 3, dan 4 bulan setelah tanam (BST). Pengukuran dilakukan mulai dari permukaan tanah sampai titik tumbuhnya.

2. Jumlah Daun (helai)

Perhitungan jumlah daun dilakukan pada saat tanaman temulawak berumur 2,3 , dan 4 BST.

3. Jumlah anakan (anakan)

Jumlah anakan diukur pada umur 2, 3, dan 4 BST yang diukur dengan menghitung jumlah anakan yang telah terbentuk dalam tiap rumpunnya (per polybag)

4. Berat rimpang segar per rumpun (gram)

Berat rimpang segar per rumpun diamati dengan cara hasil panen tiap rumpun ditimbang, yakni ada saat tanaman temulawak telah berumur 7 bulan setelah tanam. 
Analisis Data

Analisis data yang digunakan adalah analisis sidik ragam. Uji lanjut yang digunakan adalah Uji Beda Nyata Terkecil 5\% bila hasil sidik ragamnya berbeda nyata (Hanafiah, 2012).

\section{Hasil dan Pembahasan}

\section{Tinggi Tanaman Temulawak (cm)}

Hasil analisis pengaruh berbagai komposisi media tanam menunjukkan berpengaruh sangat nyata terhadap tinggi tanaman temulawak umur 2, 3 dan 4 BST. Hasil penelitian tinggi tanaman temulawak dapat dilihat pada tabel 1 di bawah ini.

Tabel 1. Data tinggi tanaman temulawak pada umur 2, 3, dan 4 BST (cm)

\begin{tabular}{cccc}
\hline Perlakuan Media & \multicolumn{3}{c}{ Tinggi tanaman $\mathbf{( c m})$} \\
\cline { 2 - 4 } Tanam & 2 BST & 3 BST & 4 BST \\
\hline M1 & $12,55 \mathrm{~b}$ & $15,25 \mathrm{~b}$ & $17,77 \mathrm{~b}$ \\
M2 & $8,55 \mathrm{a}$ & $10,47 \mathrm{a}$ & $12,12 \mathrm{a}$ \\
M3 & $16,55 \mathrm{c}$ & $20,17 \mathrm{c}$ & $23,65 \mathrm{c}$ \\
M4 & $7,50 \mathrm{a}$ & $8,40 \mathrm{a}$ & $10,20 \mathrm{a}$ \\
M5 & $8,90 \mathrm{a}$ & $10,85 \mathrm{a}$ & $13,05 \mathrm{a}$ \\
\hline BNT 5\% & 3,48 & 3,62 & 4,20 \\
\hline
\end{tabular}

Keterangan: Angka rata-rata yang diikuti oleh huruf yang sama berarti tidak berpengaruh nyata berdasarkan hasil uji BNT 5\%

Berdasarkan tabel 1, menunjukkan perlakuan M3 menunjukkan tinggi tanaman temulawak yang terbaik bila dibandingkan dengan perlakuan yang lain. Perlakuan M3 menunjukkan tinggi tanaman yang terbaik umur 2, 3 dan 4 BST yaitu berturut-turut sebesar $16,55 \mathrm{~cm}, 20,17 \mathrm{~cm}$ dan 23,65 cm. Bertambahnya tinggi tanaman adalah salah satu pertumbuhan tanaman. Tinggi tanaman sebagai indikator pertumbuhan maupun sebagai parameter yang digunakan untuk mengukur pengaruh lingkungan atau perlakuan yang diterapkan (Kusuma et al., 2013). Sekam bakar menunjukkan hasil yang terbaik. Menurut Setiawan (2019), Sekam bakar atau arang sekam adalah sekam padi kering yang dibakar dan menjadi arang. Sekam bakar memiliki keunggulan diantaranya mudah mengikat air, tidak cepat lapuk, tidak cepat menggumpal dan tidak mudah ditumbuhi fungi maupun bakteri. Sekam bakar juga merupakan media yang lebih gembur berpori dan steril. Sekam bakar juga mengandung nitrogen yang dapat meningkatkan kesuburan tanah sehingga mendukung pertumbuhan batang tanaman. Karolina et al., (2018) unsur hara nitrogen yang cukup akan membuat metabolisme tanaman budidaya akan berjalan lancar untuk menunjang pertumbuhan vegetatif tanaman khususnya penambahan tinggi tanaman. Ditambahkan oleh (Manahan et al., 2016), menyatakan bahwa terjadinya peningkatan pertumbuhan vegetatif tanaman tidak terlepas dari adanya ketersediaan unsur hara di dalam tanah. 
Penggunaan sekam dalam media tanam dapat mengikat air sehingga membantu dalam pengangkutan hara. Namun demikian penggunaan media sekam yang terlalu banyak tidak berpengaruh positif terhadap pertumbuhan tanaman (Susanti \& Larasati, 2018). Menurut Yuliarti (2007), sekam yang terbakar adalah media pertumbuhan menengah (tidak mengalami perubahan kimia) dan memiliki sifat matrik, karena sebagian besar unsur yang dikandungnya adalah karbon. Karbon dapat menjadi media tanam pertumbuhan bagi rekasi elektronik dan menjadi sangat bermanfaat bagi tanaman, dimana tanaman akan memecah senyawa mineral menjadi kation dan anion dalam media pertumbuhan melalui salah satu reaksi elektrokimia. Secara fisik, bahan bakar arang sekam memiliki kemampuan menahan air yang cukup baik. Karakter sekam bakar, yang sebagian besar terdiri dari karbon dapat menyerap air dengan sangat baik dan dapat menyimpannya di ruang pori bahkan ketika suhu mulai naik.

Pemilihan media tanam yang tepat dapat meningkatkan pertumbuhan tanaman yang baik. Media tanam yang memiliki porositas tinggi menunjang pertumbuhan akar dan mempercepat penyebaran akar sehingga menunjang pertumbuhan tanaman (Gustia, 2013). Penelitian Kartikasari et al., (2018), mengatakan aplikasi unsur hara 20\% EGC pada media tumbuh mampu memberikan tinggi tanaman temulawak yang baik dibandingkan dengan yang lain.

\section{Jumlah Daun (Helai)}

Hasil sidik ragam pengaruh media tanam menunjukkan tidak berpengaruh nyata terhadap jumlah daun temulawak umur 2 dan 3, tetapi berbeda nyata untuk jumlah daun umur 4 Bulan Setelah Tanam (BST). Hasil penelitian jumlahn daun temulawak ada pada Tabel 2.

Tabel 2. Pengaruh media tanam terhadap rata-rata jumlah daun tanaman temulawak pada umur 2 , 3, dan 4 BST (helai)

\begin{tabular}{cccc}
\hline Perlakuan Media & \multicolumn{3}{c}{ Jumlah daun (helai) } \\
\cline { 2 - 4 } Tanam & 2 BST & 3 BST & 4 BST \\
\hline M1 & 3,10 & 3,10 & $3,60 \mathrm{bc}$ \\
M2 & 2,65 & 2,90 & $\mathrm{ab}$ \\
M3 & 3,35 & 3,35 & $5,15 \mathrm{c}$ \\
M4 & 2,20 & 2,20 & $3,50 \mathrm{a}$ \\
M5 & 2,95 & 3,05 & $3,55 \mathrm{a}$ \\
\hline BNT 5\% & - & - & 1,01
\end{tabular}

Keterangan: Angka rata-rata yang diikuti oleh huruf yang sama berarti tidak berpengaruh nyata berdasarkan hasil uji BNT 5\%

Perlakuan media sekam bakar menunjukkan jumlah daun terbanyak dibandingkan perlakuan lainnya. Hal ini diduga karena sekam bakar bersifat porous dalam ketersediaan unsur hara. Sebagaimana menurut Anisa (2011) bahwa media tanam harus terjaga kelembabannya di daerah akar, cukup pertukaran udara, dan tersedia unsur hara. Pada penelitian Megawati et al., (2016), media tanam yang ditambahkan dengan bahan organik menghasilkan jumlah daun yang terbanyak dibandingkan dengan media tanam tanah dan 
pasir. Bahan organik tersebut mengandung hara yang dapat memperbaiki sifat fisik dan kimia tanah.

Penelitian Kartikasari et al., (2018), mengatakan bahwa jumlah daun yang dihasilkan oleh tanaman temulawak selain dipengaruhi oleh fakor genetik, juga dapat dipengaruhi oleh faktor lingkungan yang salah satunya adalah faktor media tanam. Akar tanaman yang mengalami kondisi perakaran yang mencekam dapat menyebabkan pertumbuhan tanaman khususnya pembentukan daun menjadi terhambat. Hal ini disebabkan karena dengan berkurangnya potensial air, maka hormon pada tanaman juga akan mengalami perubahan konsentrasi (Yuliani \& Wahyuni, 2016).

Sekam bakar bersifat gembur dan memiliki permeabilitas yang baik sehingga dapat meningkatkan kesuburan tanah dan mempunyai daya serap yang besar terhadap air. Sesuai dengan pendapat Hartatik et al., (2015), bahwa sekam padi mengandung silika yang sangat tinggi. Pemberian pupuk organik dapat memperbaiki sifat fisika tanah yaitu struktur tanah, distribusi ukuran pori, dan mengurangi fluktuasi suhu tanah.

\section{Jumlah Anakan (Anakan)}

Berdasarkan hasil sidik ragam pengaruh berbagai komposisi media tanam menunjukkan tidak berpengaruh nyata terhadap jumlah anakan temulawak umur 2, 3 dan 4 Bulan Setelah Tanam (BST). Hasil penelitian jumlah anakan temulawak dapat dilihat pada Tabel 3 di bawah ini.

Tabel 3. Pengaruh media tanam terhadap rata-rata jumlah anakan tanaman temulawak pada umur 2, 3, dan 4 BST (helai)

\begin{tabular}{cccc}
\hline Perlakuan Media & \multicolumn{3}{c}{ Jumlah anakan (anakan) } \\
\cline { 2 - 4 } Tanam & 2 BST & 3 BST & 4 BST \\
\hline M1 & 1,25 & 1,25 & 1,75 \\
M2 & 2,00 & 2,00 & 2,00 \\
M3 & 1,00 & 1,00 & 1,25 \\
M4 & 1,33 & 1,33 & 1,33 \\
M5 & 1,33 & 1,33 & 1,50 \\
\hline
\end{tabular}

Berdasarkan tabel 3 diatas menunjukkan bahwa perlakuan media sekam yang terbaik bila dibandingkan dengan perlakuan lainnya. Hal ini diduga penggunaan bahan organik sekam mampu menyediakan unsur hara makro maupun mikro yang dibutuhkan oleh tanaman. Sesuai dengan pendapat Kurnia \& Suminarti (2020), menyatakan penggunaan bahan organik pada media tanam 30 hari sebelum tanam menghasilkan jumlah anakan total tertinggi dibandingkan secara bersamaan atau 15 hari sebelum tanam. Jumlah anakan total merupakan hasil dari fotosintesis yang menghasilkan asimilat.

\section{Berat Rimpang Segar per Rumpun (gram)}

Berdasarkan hasil sidik ragam pengaruh berbagai komposisi media tanam menunjukkan tidak berpengaruh nyata terhadap berat rimpang segar per rumpun (gram). Hasil penelitian berat rimpang segar per rumpun tanaman temulawak dapat dilihat pada tabel 4 dibawah ini. 
Tabel 4. Berat rimpang segar per rumpun tanaman temulawak

\begin{tabular}{cc}
\hline Perlakuan Media Tanam & Berat rimpang segar per rumpun (gram) \\
\hline M1 & 65,25 \\
M2 & 60,50 \\
M3 & 108,50 \\
M4 & 77,00 \\
M5 & 71,00 \\
\hline
\end{tabular}

Meskipun hasil sidik ragam menunjukkan berbeda tidak nyata terhadap rata-rata berat bersih rimpang temulawak, namun perlakuan sekam bakar (M3) menunjukkan hasil pertumbuhan vegetatif yang terbaik bila dibandingkan dengan perlakuan lainnya. Berat bersih rimpang temulawak berkolerasi positif dengan tinggi tanaman dan jumlah daun. Pada penelitian Hadipoentyanti \& Syahid (2001), pertumbuhan benih kultur invitro memiliki jumlah daun yang paling banyak akan menghasilkan berat rimpang tertinggi, dimana media tanam tanah dan pupuk kandang menghasilkan jumlah daun sebanyak 23 helai dan berat rimpang sebesar 419,2 g.

Media sekam bakar (M3) menghasilkan berat bersih rimpang temulawak yang tinggi. Media tanam dengan penambahan sekam bakar memiliki ruang-ruang (porous) yang dapat ditembus oleh rimpang temulawak. Sifat gembur ini menyebabkan penyerapan unsur hara semakin baik. Selain itu, sekam bakar juga mengandung $\mathrm{Si}, \mathrm{O}, \mathrm{P}$, dan $\mathrm{K}$ yang berasal dari proses pembakaran suhu tinggi. Penambahan sekam bakar pada media tanam dapat meningkatkan kadar $\mathrm{P}$ dan $\mathrm{K}$. Makronutrien $\mathrm{P}$ dan $\mathrm{K}$ merupakan makronutrien yang penting dalam pembentukan rimpang (Kusnadi \& Nugraha, 2018).

Perlakuan media serbuk gergaji (M5) menunjukkan hasil berat rimpang segar yang rendah, hal ini dikarenakan serbuk gergaji mengandung lignin yang menyebabkan nilai $\mathrm{C}$ (karbon) organik yang tinggi. Menurut (Muliawati, 2001), menyatakan bahwa serbuk gergaji merupakan pupuk yang lambat tersedia atau lambat diserap tanaman sehingga lama untuk terdekomposisi dengan baik.

\section{Kesimpulan}

Berbagai jenis media tanam sangat berpengaruh nyata terhadap tinggi tanaman dan jumlah daun pada umur 4 BST, namun tidak berpengaruh nyata terhadap parameter lainnya. Perlakuan media tanam sekam bakar (M3) merupakan perlakuan yang terbaik, karena menghasilkan berat rimpang segar per rumpun yang terberat yaitu 108,50 gram.

\section{Daftar Pustaka}

Afifah, E., \& Lentera, T. (2005). Tanaman Obat untuk Mengatasi Hepatitis. AgroMedia Pustaka.

Anisa, S. (2011). Pengaruh Komposisi Media Tumbuh Terhadap Perkecambahan Benih dan Pertumbuhan Bibit Andalas (Morus Macroura Miq.). Skripsi. Fakultas Pertanian. Universitas Andalas, Padang. 
Gustia, H. (2013). Pengaruhpenambahan Sekam Bakar Pada Media Tanam Terhadap Pertumbuhan Dan Produksi Tanaman Sawi (Brassica Juncea L.). E-Journal Widya Kesehatan Dan Lingkungan, 1(1), 12-17.

Hadipoentyanti, E., \& Syahid, S. F. (2001). Pertumbuhan dan Produksi Rimpang Temu Lawak di Polybag yang Benihnya Hasil Kultur In Vitro. Jurnal Biologi Indonesia, III(2), 118-125. https://doi.org/http://dx.doi.org/10.14203/jbi.v3i2.3481

Hanafiah, K. A. (2012). Rancangan Percobaan (Teori dan Aplikasi). Raja Grafindo Persada.

Hartatik, W., Husnain, \& Widowati, L. R. (2015). Peranan Pupuk Organik Dalam Peningkatan Produktivitas Tanah dan Tanaman. Jurnal Sumberdaya Lahan, 9(2), 107-120. https://doi.org/http://dx.doi.org/10.21082/jsdl.v9n2.2015.\%25p

Karolina, A., Winata, I. N. A., \& Oktavianawati, I. (2018). Pengaruh Fermentasi Oleh Effective Microorganis-4 (EM-4) Terhadap Kadar Kurkumin Ekstrak Rimpang Temulawak (Curcuma xanthorrhiza Roxb.). Berkala Sainstek, 6(2), 84-88. https://doi.org/10.19184/bst.v6i2.9229

Kartikasari, A., Nurazizah, \& Nuhayati, E. (2018). Pertumbuhan Temulawak (Curcuma xanthoriza Roxs) UB 2 Musim Kemarau Pada Berbagai Kombinasi Pupuk EGC (Enriched Granular Compost) dan N k. Jurnal Produksi Tanaman, 6(1), 146-153.

Kurnia, R. F., \& Suminarti, N. E. (2020). Pengaruh Waktu Aplikasi dan Sumber Bahan Organik pada Pertumbuhan dan Hasil Tanaman Jahe Merah (Zingiber officinale Var. Rubrum Rhizoma). Jurnal Produksi Tanaman, 8(1), 112-119.

Kusnadi, \& Nugraha, P. P. (2018). Pertumbuhan Rimpang dan Kadar Kurkumin Temulawak Melalui Pemberian Kompos Daun Jati, Air Kelapa dan Limbah Cair Ampas Tahu. PSEJ (Pancasakti Science Education Journal), 3(2), 73-82. https://doi.org/https://doi.org/10.24905/psej.v3i2.102

Kusuma, A. H., Izzati, M., \& Saptiningsih, E. (2013). Pengaruh Penambahan Arang dan Abu Sekam dengan Proporsi yang Berbeda terhadap Permeabilitas dan Porositas Tanah Liat serta Pertumbuhan Kacang Hijau (Vigna radiata L). Buletin Anatomi Dan Fisiologi, 21(1), 1-9. https://doi.org/https://doi.org/10.14710/baf.v21i1.6260

Langgeng, R. H., Tini, E. W., \& Prakoso, B. (2019). Pertumbuhan Bibit Cabai pada Media Serbuk Gergaji Kayu Sengon dengan Perendaman Air. Agrotechnology Research Journal, 3(2), 97-102. https://doi.org/10.20961/agrotechresj.v3i2.34421

Manahan, S., Idwar, \& Wardati. (2016). Pengaruh Pupuk NPK dan Kascing Terhadap Pertumbuhan Kelapa Sawit (Elaeis guineensis Jacq.) Fase Main Nursery. JOM Faperta Vol., 3(2), 1-10.

Megawati, Sahiri, N., \& Andrianton. (2016). Pengaruh Jenis Rimpang Dan Komposisi Media Tanam Terhadap Pertumbuhan Bibit Temulawak (Curcuma xanthorrhiza Roxb.). Agrotekbis : E-Jurnal Ilmu Pertanian, 4(3), 244-251.

Muliawati, E. S. (2001). Kajian Tingkat Serapan Hara, Pertumbuhan dan Produksi Sambiloto (Androgaphis paniculata Ness.) pada Beberapa Komposisi Media Tanam dan Tingkat Pengairan. Prosiding Simposium Nasional II Tumbuhan Obat Dan Aromatik. APINMAP. Bogor, 8-10 Agustus 2001, 8-10.

Nihayati, E. (2016). Peningkatan Produksi dan Kadar Kurkumin Temulawak. Universitas Brawijaya Press.

Putri, D. (2006). Pengaruh Jenis Media Tanam terhadap Pertumbuhan dan Hasil Tanaman Sawi Caisin. Jurnal Agrobis, 1(1). 
Setiawan, A. (2019). Buku Pintar Hidroponik. Laksana.

Susanti, D., \& Larasati, O. G. D. (2018). Pengaruh Komposisi Media Tanam Pada Pembibitan Meniran (Phyllanthus niruri L.). Jurnal Pengembangan Penyuluhan Pertanian, 15(28), 1-9. https://doi.org/http://dx.doi.org/10.36626/jppp.v15i28.9

Yuliani, \& Wahyuni, S. (2016). Pengaruh Komposisi Pupuk Kandang Terhadap Pertumbuhan dan Hasil Tanaman Kubis Bunga (Brassica oleraceae var botrits $\mathrm{L}$ ) Dataran Rendah. Jurnal AGROQUA, 12(2).

Yuliarti, N. (2007). Media Tanam dan Pupuk untuk Anthurium Daun. AgroMedia Pustaka. 